\title{
Hematologic, serum biochemistry and urinary values for captive Crab-eating Fox (Cerdocyon thous) in São Paulo state, Brazil ${ }^{1}$
}

\author{
Cláudio R.S. Mattoso ${ }^{2 *}$, Lilian S. Catenacci ${ }^{3}$, Suzane L. Beier ${ }^{4}$, Raimundo S. Lopes ${ }^{2}$ \\ and Regina K. Takahira ${ }^{2}$
}

\begin{abstract}
Mattoso C.R.S., Catenacci L.S., Beier S.L., Lopes R.S. \& Takahira R.K. 2012. Hematologic, serum biochemistry and urinary values for captive Crab-eating Fox ( $\mathrm{Cer}$ docyon thous) in São Paulo state, Brazil. Pesquisa Veterinária Brasileira 32(6):559-566. Laboratório Clínico Veterinário, Departamento de Clínica Veterinária, Faculdade de Medicina Veterinária e Zootecnia, Universidade Estadual Paulista, Campus de Botucatu, Distrito de Rubião Junior s/n, Botucatu, SP 18618-970, Brazil. E-mail: crsmattoso@yahoo.com

The importance of studies with hematological, serum biochemistry and urinary values of Crab-eating Fox (Cerdocyon thous) is based on the need for health care and maintenance of those populations. This paper has the objective to investigate hematological, serum biochemistry and urinary physiological parameters of the Crab-eating fox, comparing gender and age differences. Blood samples were collected in 2003 from 52 animals of different Zoos in São Paulo state, Brazil; $7 \mathrm{~mL}$ of blood was used to obtain a complete blood cell count (CBC) and the profile of the serum biochemistry. Moreover, $5 \mathrm{~mL}$ of urine were collected for analysis. There was no difference in values for male and female animals, as for the CBC and serum biochemistry. Some hematological and serum biochemical parameters were influenced by age, showing significant differences. Urinalysis results were just demonstrated in a descriptive form. The studied values were, RBC $4.35 \pm 0.73 \times 10^{6} / \mu \mathrm{L}$, WBC $7.72 \pm 3.66 \times 10^{3}$ $/ \mu \mathrm{L}$ (predominance of segmented neutrophils), platelets $227.06 \pm 111.58 \times 10^{3} / \mu \mathrm{L}$, urea $43.06 \pm 14.28 \mathrm{mg} / \mathrm{dL}$ and creatinine $1.03 \pm 0.24 \mathrm{mg} / \mathrm{dL}$. Hematological, serum biochemistry and urinary values obtained in this study can be used as physiological values of the captive Crab-eating Fox. It is possible to conclude that wild species need their own reference values, differentiating animals in captivity from free-ranging animals.
\end{abstract}

INDEX TERMS: Crab-eating Fox, Cerdocyon thous, wild animals, blood, urinalysis, Brazil.

RESUMO.- [Valores hematologicos, de bioquímica sérica e urinários para Cachorro-do-mato (Cerdocyon thous) de cativeiro no estado de São Paulo.] A importância do estudo dos valores hematológicos, de bioquímica sérica e urinários de Cachorro-do-mato (Cerdocyon

\footnotetext{
${ }^{1}$ Received on July 7, 2011.

Accepted for publication on February 28, 2012.

${ }^{2}$ Laboratório Clínico Veterinário, Departamento de Clínica Veterinária, Faculdade de Medicina Veterinária e Zootecnia, Universidade Estadual Paulista (Unesp), Campus de Botucatu, Distrito de Rubião Junior s/n, Botucatu, SP 18618-970, Brazil. *Corresponding author: crsmattoso@yahoo.com

${ }^{3}$ Escola de Medicina Veterinária, Universidade Federal do Piauí (UFPI), Diretora da Associação Brasileira de Veterinários de Animais Selvagens (Abravas), BR 135 Km 03, Bom Jesus, PI 64900-000, Brazil.

${ }^{4}$ Departamento de Medicina Veterinária, Centro de Ciências Agroveterinárias, Universidade do Estado de Santa Catarina (UDESC), Av. Luiz de Camões 2090, Lages, SC 88520-000, Brazil.
}

thous) baseia-se na necessidade de cuidados e manutenção da sanidade destas populações. Este estudo visou investigar os parâmetros fisiológicos hematológicos, de bioquímica sérica e urinários dos Cachorros-do-mato de cativeiro, comparando as possíveis diferenças sexuais e de faixa etária. Foram colhidas amostras de sangue de 52 animais, pertencentes a diversos Zoológicos do Estado de São Paulo, Brasil. Foram colhidos cerca de $7 \mathrm{~mL}$ de sangue, que foram utilizados para se obter os valores hematológicos e o perfil de bioquímica sérica. Também foram colhidos $5 \mathrm{~mL}$ de urina para realização da urinálise. Não se encontraram diferenças entre os valores obtidos para machos e fêmeas tanto na hematologia, quanto na bioquímica sérica. Alguns parâmetros hematológicos e de bioquímica sérica foram afetados pela idade, mostrando diferenças significativas. Os resultados da urinálise foram demonstrados apenas em forma descritiva. Os principais valores 
encontrados foram, hemácias $4,35 \pm 0,73 \times 10^{6}$ células $/ \mu \mathrm{L}$, leucócitos totais $7,72 \pm 3,66 \times 10^{3}$ células $/ \mu \mathrm{L}$ (predomínio de neutrófilos segmentados), plaquetas $227,06 \pm 111,58$ x $10^{3}$ células / $\mu \mathrm{L}$, ureia $43,06 \pm 14,28 \mathrm{mg} / \mathrm{dL}$ e creatinina $1,03 \pm 0,24 \mathrm{mg} / \mathrm{dL}$. Os valores hematológicos, de bioquímica sérica e urinários obtidos neste estudo podem ser utilizados como valores fisiológicos de Cachorros-do-mato de cativeiro. Pode-se concluir que as espécies silvestres necessitam de seus próprios valores de referência com necessidade de se diferenciar animais em cativeiro de animais de vida livre.

TERMOS DE INDEXAÇÃO: Cachorro-do-mato, Cerdocyon thous, animais silvestres, sangue, urinálise, Brasil.

\section{INTRODUCTION}

Crab-eating Fox (Cerdocyon thous) belongs to the order Carnivora which has 7 families, among them there is the Canidae, divided in 3 subfamilies: Caninae, Simocyoninae and Otocyoninae. The genus Cerdocyon and the species $C$. thous belong to the Caninae subfamily (Nowak 1999). This fox is considered a medium sized animal (around 5 to 8 $\mathrm{kg}$ and $65 \mathrm{~cm}$ ) (Berta 1982, Rodrigues \& Auricchio 1994, McDonald \& Courtenay 1996), with no sexual dimorphism, and it is very common in South America. It is omnivorous, feeding on crabs, lizards, insects, small mammals, and birds, besides eggs, offal, and fruits (Rodrigues \& Auricchio 1994).

The species is not threatened from extinction mainly due to its large distribution in South America and its potential for adapting in modified environments. However, considering the increase in human occupation around natural areas it is common to observe these animals in the peridomiciliary habitat, which can become a natural reservoir of several zoonosis (Berta 1982, Motta-Júnior et al. 1994, Facure \& Monteiro-Filho 1996).

Hematology and clinical biochemistry represent an important support for diagnosis in Veterinary Medicine. They are used to evaluate the health of animals; however, they have limited use concerning wild animals due to the lack of reference values (Courtenay et al. 2001). Also, a pre-requirement to evaluate the sensibility of any wildlife species for diseases is to characterize their normal values (Karesh et al. 1995).

Studies about these parameters for wild canidae are rare (Wallach \& Boever 1983). Some authors related hematological and biochemical values for Maned wolves (Chrysocyon brachyurus) with a variation from 6 to 32 animals (Busch 1980, Cavaliero 1989, Crooks et al. 2000, Novais et al. 2005, May-Junior et al. 2009). Other canids were studied for hematological and/or biochemical values, among them swift fox (Vulpes velox) (Mainka 1988), silver fox (Vulpes vulpes) (Zhan et al. 1991), wild dogs (Lycaon pictus) (van Heerden et al. 1991), gray wolves (Canis lupus) (Constable et al. 1998), and golden jackals (Canis aureus syriacus) (Aroch et al. 2005); but urinalysis values were not found in literature.

One of the first studies for Crab-eating Fox was accomplished in 1953, with just four animals (Hoehne \& Rosenfeld 1953). Besides this research, some hematological and serum biochemical parameters were published for nine C. thous from Foz do Iguaçú/PR, Brazil (Santos 1999), and the same parameters for 12 (Neves-Júnior et al. 2006, Santos-Júnior et al. 2006) and 16 (Novais et al. 2005) Crab-eating Fox, being wildlife and captive animals, respectively. The reference values found in the literature should provide the initial basis for the interpretation of laboratorial tests on wildlife animals. However it is necessary to characterize the regional values (Almosny \& Monteiro 2007).

This research was performed due to the few studies carried out with Crab-eating Fox, the reduced number of individuals used in these works and the absence of reference values for animals from Southeastern Brazil. Its objective is to investigate hematological, biochemical and urinary parameters of captive $C$. thous from São Paulo State - Brazil, evaluating their gender and age influences.

Table 1. Hematological values (mean \pm SD and range) for male (24) and female (28) captive Crab-eating fox (Cerdocyon thous) in São Paulo state, Brazil

\begin{tabular}{|c|c|c|c|c|c|c|}
\hline \multirow{2}{*}{$\begin{array}{c}\text { Hematological } \\
\text { parameters }\end{array}$} & \multicolumn{2}{|c|}{ Male } & \multicolumn{2}{|c|}{ Female } & \multicolumn{2}{|c|}{ Both sex } \\
\hline & Mean \pm SD & Range & Mean \pm SD & Range & Mean \pm SD & Range \\
\hline $\operatorname{RBC}\left(10^{6} / \mathrm{uL}\right)^{\mathrm{a}}$ & $4.27 \pm 0.87$ & $3.1-6.08$ & $4.44 \pm 0.55$ & $3.05-$ & $4.35 \pm 0.73$ & $3.05-6.08$ \\
\hline Hemoglobi & $12.90 \pm 2.41$ & $10-18.1$ & $13.41 \pm 1.38$ & $10.1-1$ & $13.15 \pm 1.98$ & $10-18.1$ \\
\hline $\operatorname{PCV}(\%)^{\mathrm{b}}$ & $38.12 \pm 6.91$ & $28-53$ & $40.13 \pm 3.85$ & $30-46$ & $39.08 \pm 5.69$ & $28-53$ \\
\hline $\operatorname{MCV}(\mathrm{fL})^{\mathrm{c}}$ & $89.78 \pm 4.81$ & $80.70-98.45$ & $90.90 \pm 6.16$ & 79.11-100 & $90.32 \pm 5.47$ & 78.11-100 \\
\hline $\mathrm{MCH}(\mathrm{pg})^{\mathrm{d}}$ & $30.41 \pm 2.21$ & 28.11-34.92 & $30.34 \pm 1.96$ & $28.95-33.11$ & $30.38 \pm 2.07$ & 28.11-34.92 \\
\hline $\operatorname{MCHC}(\%)^{\mathrm{e}}$ & $33.90 \pm 2.13$ & $30.54-37.88$ & $33.44 \pm 1.98$ & $30.22-38.46$ & $33.68 \pm 2.05$ & $30.22-38.46$ \\
\hline Metarrubricytes & $0.16 \pm 0.37$ & $0-1$ & $0.22 \pm 0.42$ & $0-1$ & $0.19 \pm 0.39$ & $0-1$ \\
\hline WBC $\left(10^{3} / \mathrm{uL}\right)^{\mathrm{f}}$ & $7.35 \pm 2.75$ & $3.4-14.2$ & $8.12 \pm 4.47$ & $3.70-23.2$ & $7.72 \pm 3.66$ & $3.4-23.20$ \\
\hline Band neutrophils $\left(10^{3} / \mathrm{uL}\right)$ & $0.02 \pm 0.07$ & $0-0.25$ & $0.05 \pm 0.16$ & $0-0.7$ & $0.04 \pm 0.12$ & $0-0.7$ \\
\hline Segmented neutrophils $\left(10^{3} / \mathrm{uL}\right)$ & $4.38 \pm 2.40$ & $1.80-11.79$ & $4.89 \pm 3.05$ & $1.46-13.53$ & $4.62 \pm 2.71$ & $1.46-13.53$ \\
\hline Lymphocytes $\left(10^{3} / \mathrm{uL}\right)$ & $1.31 \pm 0.72$ & $0.21-2.94$ & $1.45 \pm 0.90$ & $0.44-3.99$ & $1.38 \pm 0.81$ & $0.21-3.99$ \\
\hline Eosinophils $\left(10^{3} / \mathrm{uL}\right)$ & $1.23 \pm 0.97$ & $0-3.21$ & $1.20 \pm 0.92$ & $0.17-3.94$ & $1.22 \pm 0.94$ & $0-3.94$ \\
\hline Basophils $\left(10^{3} / \mathrm{uL}\right)$ & $0.02 \pm 0.10$ & $0-0.52$ & $0.01 \pm 0.02$ & $0-0.1$ & $0.02 \pm 0.08$ & $0-0.52$ \\
\hline Monocytes $\left(10^{3} / \mathrm{uL}\right)$ & $0.38 \pm 0.22$ & $0.04-1.13$ & $0.52 \pm 0.48$ & $0.19-2.55$ & $0.45 \pm 0.37$ & $0.04-2.55$ \\
\hline Platelets $\left(10^{3} / \mathrm{uL}\right)$ & $203.47 \pm 99.03$ & $\begin{array}{lll}3 & 18-349 & 2\end{array}$ & $252.71 \pm 120.75$ & $5105-6362$ & $227.06 \pm 111.58$ & $3 \quad 18-636$ \\
\hline
\end{tabular}

${ }^{\mathrm{a}}$ Red blood cell; ${ }^{\mathrm{b}}$ Packed Cell Volume; ${ }^{\mathrm{c}}$ Mean Corpuscular Volume; ${ }^{\mathrm{d}}$ Mean Corpuscular Hemoglobin; ${ }^{\mathrm{e}}$ Mean Corpuscular Hemoglobin Concentration; ${ }^{\mathrm{f}}$ White blood cell. 


\section{MATERIALS AND METHODS}

In 2003, this study was conducted in 17 zoos from São Paulo State, as well as the School of Veterinary Medicine and Animal Science at São Paulo State University (Unesp), Campus Botucatu, São Paulo state, Brazil. A total of 52 crab-eating fox (Cerdocyon thous), 24 males and 28 females, kept under captive conditions in zoos were included, except animals younger than six months and pregnant or lactating females.

All the Crab-eating Foxes showed good corporal status and good health. They were fed with meat (chicken and beef), commercial pet food, fruits and vegetables.

The animals were divided by gender (male and female) and age (adults, more than one year-old; sub-adults, between six months and one year-old), according to the division made by other authors (Smith \& Rongstad 1980, Crooks 2000). Adult animals weighed between 5 to $10 \mathrm{~kg}$; sub-adults had a weight lower than $5 \mathrm{Kg}$. The study was approved by the Ethics Committee in Animal Experimentation of the School of Veterinary Medicine and Animal Science, Unesp, Botucatu Campus, São Paulo.

Approximately $7 \mathrm{~mL}$ of blood were collected from the jugular vein of all animals, after physical and chemical restraint, following different anesthetic protocols, according to the handling of each zoo. The blood was collected with needles (BD PrecisionGlide $0.70 \times 30 \mathrm{~cm} / 22 \mathrm{G} 1$ 1/4, BD, Franklin Lakes, NJ 07417, USA) and syringes (BD Plastipak 5 and $10 \mathrm{~mL}, \mathrm{BD}$, Franklin Lakes, NJ 07417, USA), preserved in vacuum glass bottles containing EDTA at 10\% (Vacutainer EDTA K2 4mL, BD, Franklin Lakes, NJ 07417, USA) and bottles without anticoagulant (Vacutainer Gel BD SST II Advance 5mL, BD, Franklin Lakes, NJ 07417, USA). Blood smears were accomplished after collection. Other blood smears were performed using capillary blood from the top of the animals' ears for the search of blood parasites. Urine $(5 \mathrm{~mL})$ was also collected by urethral catheterization (urethral tube $\mathrm{n} \div$ 6, Mark Med, Bragança Paulista, SP 12929-460, Brazil) for urinalysis.

All samples were kept under refrigeration, since the collection until the processing in the Veterinary Clinical Laboratory of the School of Veterinary Medicine and Animal Science, at São Paulo State University. All samples were processed until 24 hours after the collection.

The Red Blood Cell Count (RBC) and White Blood Cell Count (WBC) were accomplished in automatic blood cell counter (CC510, Celm; Barueri, SP 06454-070, Brazil), and the determination of hemoglobin concentration was made in the hemoglobinometer (HB520, Celm; Barueri, SP 06454-070, Brazil).

The packed cell volume (PCV) was made by microhematocrit method (Jain 1986) using microcentrifuge (Centrimicro, model 211, Fanem, São Paulo, SP 02033-020, Brazil). Fibrinogen was estimated by heat precipitation - refractometer method (Kaneko 1997) (T2-NE Clinical, ATAGO, Bellevue, WA 98005,USA).

Platelet count was made in the Neubauer-counting chamber (Neubauer improved, LaborOptik, 61350 Bad Homburg, Hessen, Germany), using ammonium oxalate (Amomonium oxalate PA, Vetec, Duque de Caxias, RJ 25250-000, Brazil) 1\%. Blood smears were stained with a Romanowsky-type stain (rapid panoptic method-Diff-Quick stain, Laborclin, Pinhais, PR 83321-210, Brazil) for the differential WBC count in 100 cells and for the search of blood parasites.

To analyze the biochemical parameters (Urea, Creatinine, Alanine Aminotransferase - ALT, Alkaline phosphatase - ALP, Gamma-Glutamyl Transferase - GGT, Serum Total Protein - TP, Albumin - Alb and Globulin - Glob), blood (kept in glass bottle without anticoagulant) was centrifuged $(1,710 \mathrm{~g})$, and the serum was obtained. This material was stored in a freezer $-80^{\circ} \mathrm{C}$ until the moment of the dosages. The serum was used in several biochemical dosages made in semi-automatic devices (SB 190®, Celm, Barueri, SP 06454-070, Brazil) with support of commercial kits (Celm, Barueri, SP 06454-070, Brazil).

Urinalysis tests were made using a urine dipstick (Combur®10, Roche, Basel, Basel Stadt, 4070, Switzerland) and its specific gravity was obtained by refractometer reading (T2-NE Clinical, ATAGO, Bellevue, WA 98005,USA). Urine was centrifuged (850g) for sediment analysis.

To compare the genus and the age, it was used Wilcoxon's signed rank test. All analyses were done with the use of commercial software (SAS for Windows, v.9.2., SAS Institute Inc., Cary, NC 27513 , USA). The level of significance (5\%) or the correspondent p-value was considered. Urinary parameters were demonstrated in a descriptive way, because only male animals were evaluated, and just one animal belongs to the sub-adult class.

\section{RESULTS}

This is the first systematic evaluation of hematological, serum biochemistry and urinary parameters on captive Cerdocyon thous, from several zoos in São Paulo State, Brazil. This research supplies several data to characterize physiological values for this species.

\section{Hematology}

Hematological values were not affected by gender, this way; results have been shown separately and follow all together (Table 1). Considering the 52 animals, blood parasites were not found in any of the blood smears accomplished; neither the blood from the top of the ears nor the total blood with EDTA.

The following hematological parameters showed significant statistical differences ( $\mathrm{p}<0.05)$ among sub-adult and adult animals: Hemoglobin, Mean Corpuscular Hemoglobin (MCH), Mean Corpuscular Hemoglobin Concentration (MCHC), WBC, band and segmented Neutrophils, and Lymphocytes (Table 2).

\section{Serum biochemistry}

As hematological parameters, serum biochemistry values were not affected by gender, so values considering male and female animals were shown separately and follow together (Table 3). Some parameters of serum biochemistry were affected by aging, showing statistical differences $(\mathrm{p}<0.05)$ between sub-adult and adult animals, as urea, ALP, GGT and fibrinogen (Table 4).

\section{Urinalysis}

The crab-eating fox physical examination of urinalysis seemed to be similar to the one of domestic dogs. They had yellow color, limpid aspect with variation of slightly cloudy, and a "sui generis" odor for the species, as proposed for domestic dogs (Lees et al. 1994).

The values found as for specific gravity, $\mathrm{pH}$ and glycosuria (Table 5) were similar to the values of reference for the domestic dogs. However, values for proteinuria (Table 5) were higher than those proposed for domestic dogs (Lees et al. 1994).

No animal showed alterations by the presence of acetone, urobilinogen or bile salt, and just 8.3\% (two in 24 
Table 2. Hematological values (mean \pm SD and range) for sub-adult (05) and adult (47) captive Crab-eating fox (Cerdocyon thous) in São Paulo state, Brazila

\begin{tabular}{|c|c|c|c|c|}
\hline \multirow[t]{2}{*}{ Hematological parameters } & \multicolumn{2}{|c|}{ Subadult } & \multicolumn{2}{|c|}{ Adult } \\
\hline & $\mathrm{Mean} \pm \mathrm{SD}$ & Range & Mean+SD & Range \\
\hline $\mathrm{RBC}\left(10^{6} / \mathrm{uL}\right)$ & $4.12 \pm 0.36$ & $3.73-4.56$ & $4.41 \pm 0.66$ & $3.05-6.08$ \\
\hline Hemoglobin (g/dL) & $11.43 \pm 0.94(\mathrm{a})$ & $10.3-12.6$ & $13.44 \pm 1.71(\mathrm{~b})$ & 10-18.1 \\
\hline PCV $(\%)$ & $37.00 \pm 2.45$ & $34-40$ & $39.67 \pm 5.04$ & $28-53$ \\
\hline MCV (fL) & $90.00 \pm 2.97$ & 87.47-93.67 & $90.42 \pm 5.51$ & 79.11-100 \\
\hline MCH (pg) & $27.77 \pm 0.99(\mathrm{a})$ & 26.71-29.11 & $30.65 \pm 1.89$ (b) & $25.95-34.92$ \\
\hline $\mathrm{MCHC}(\%)$ & $30.85 \pm 0.54(a)$ & $30.29-31.50$ & $33.95 \pm 1.96$ (b) & $30.22-38.46$ \\
\hline Metarrubricytes & 0 & 0 & $0.21 \pm 0.41$ & $0-1$ \\
\hline WBC $\left(10^{3} / \mathrm{uL}\right)$ & $11.93 \pm 3.05(\mathrm{a})$ & $10.3-16.5$ & $7.37 \pm 3.49(\mathrm{~b})$ & $3.4-23.2$ \\
\hline Band neutrophils $\left(10^{3} / \mathrm{uL}\right)$ & $0.13 \pm 0.16(\mathrm{a})$ & $0-0.33$ & $0.02 \pm 0.11(\mathrm{~b})$ & $0-0.7$ \\
\hline Segmented neutrophils $\left(10^{3} / \mathrm{uL}\right)$ & $8.84 \pm 3.18(a)$ & $6.49-13.53$ & $4.25 \pm 2.35(\mathrm{~b})$ & $1.46-12.99$ \\
\hline Lymphocytes $\left(10^{3} / \mathrm{uL}\right)$ & $1.99 \pm 0.44(\mathrm{a})$ & $1.47-2.47$ & $1.33 \pm 0.82(\mathrm{~b})$ & $0.21-3.99$ \\
\hline Eosinophils $\left(10^{3} / \mathrm{uL}\right)$ & $0.48 \pm 0.47$ & $0-0.93$ & $1.30 \pm 0.95$ & $0.27-3.94$ \\
\hline Basophils $\left(10^{3} / \mathrm{uL}\right)$ & 0 & 0 & $0.02 \pm 0.08$ & $0-0.52$ \\
\hline Monocytes $\left(10^{3} / \mathrm{uL}\right)$ & $0.48 \pm 0.21$ & $0.21-0.66$ & $0.44 \pm 0.39$ & $0.04-2.55$ \\
\hline Platelets $\left(10^{3} / \mathrm{uL}\right)$ & $268.00 \pm 19.88$ & $249-291$ & $233.27 \pm 112.63$ & $18-636$ \\
\hline
\end{tabular}

${ }^{a}$ Means in the same column (line) with different superscripts are significantly different $(\mathrm{P}<0.05)$.

Table 3. Serum Biochemistry values (mean \pm SD and range) for male (24) and female (28) captive Crab-eating fox (Cerdocyon thous) in São Paulo state, Brazil

\begin{tabular}{|c|c|c|c|c|c|c|}
\hline \multirow{2}{*}{$\begin{array}{l}\text { Serum biochemistry } \\
\text { parameters }\end{array}$} & \multicolumn{2}{|c|}{ Male } & \multicolumn{2}{|c|}{ Female } & \multicolumn{2}{|c|}{ Both sex } \\
\hline & Mean \pm SD & Range & Mean \pm SD & Range & Mean \pm SD & Range \\
\hline Urea (mg/dL) & $45.29 \pm 16.97$ & $23-87$ & $41.14 \pm 11.47$ & $22-74$ & $43.06 \pm 14.28$ & $22-87$ \\
\hline Creatinine (mg/dL) & $1.05 \pm 0.25$ & $0.5-1.5$ & $1.01 \pm 0.24$ & $0.7-1.4$ & $1.03 \pm 0.24$ & $0.5-1.5$ \\
\hline $\operatorname{ALT}(I U / L)^{a}$ & $37.63 \pm 45.27$ & $2.6-231.5$ & $35.89 \pm 36.67$ & $11.5-179.1$ & $36.69 \pm 40.46$ & $2.6-231.5$ \\
\hline $\operatorname{ALP}(\mathrm{IU} / \mathrm{L})^{\mathrm{b}}$ & $51.45 \pm 61.85$ & $8.2-233.5$ & $50.92 \pm 57.79$ & 8.2-267 & $59.81 \pm 85.50$ & $8.2-267$ \\
\hline GGT $(\mathrm{IU} / \mathrm{L})^{\mathrm{c}}$ & $2.28 \pm 1.34$ & $0.6-5$ & $2.27 \pm 1.25$ & $0.6-5.7$ & $2.27 \pm 1.28$ & $0.6-5.7$ \\
\hline Total Protein (serum) (g/dL) & $6.32 \pm 1.22$ & $4.6-8.6$ & $6.66 \pm 0.84$ & $5.5-9.4$ & $6.50 \pm 1.04$ & $4.6-9.4$ \\
\hline Albumin $(\mathrm{g} / \mathrm{dL})$ & $3.00 \pm 0.89$ & $2.5-6.2$ & $2.96 \pm 0.49$ & $2-3.9$ & $2.98 \pm 0.70$ & $2-6.2$ \\
\hline Globulin (g/dL) & $3.32 \pm 1.06$ & $1.9-6.1$ & $3.70 \pm 1.08$ & $2.5-7.5$ & $3.52 \pm 1.08$ & $1.9-7.5$ \\
\hline Fibrinogen $(\mathrm{mg} / \mathrm{dL})$ & $176 \pm 96.95$ & $100-400$ & $182.61 \pm 115.41$ & $100-600$ & $179.17 \pm 105.10$ & $100-600$ \\
\hline
\end{tabular}

${ }^{\mathrm{a}}$ Alanine aminotransferase; ${ }^{\mathrm{b}}$ Alkaline phosphatase; ${ }^{\mathrm{c}}$ Gama Glutamyltrasferase.

Table 4. Serum Biochemistry values (mean \pm SD and range) for sub-adult (05) and adult (47) captive Crab-eating fox (Cerdocyon thous) in São Paulo state, Brazil ${ }^{a}$

\begin{tabular}{|c|c|c|c|c|}
\hline \multirow{2}{*}{$\begin{array}{l}\text { Serum biochemistry } \\
\text { parameters }\end{array}$} & \multicolumn{2}{|c|}{ Subadult } & \multicolumn{2}{|c|}{ Adult } \\
\hline & Mean \pm SD & Range & Mean \pm SD & Range \\
\hline Urea (mg/dL) & $31.75 \pm 5.12(\mathrm{a})$ & $27-39$ & $43.09 \pm 13.09(b)$ & $22-85$ \\
\hline Creatinine (mg/dL) & $0.95 \pm 0.21$ & $0.7-1.2$ & $1.04 \pm 0.23$ & $0.5-1.5$ \\
\hline ALT (IU/L) & $18.45 \pm 4.81$ & $11.5-22.5$ & $38.97 \pm 41.88$ & $2.6-231.5$ \\
\hline ALP (IU/L) & $232.43 \pm 25.03(\mathrm{a})$ & 209.7-267 & $35.73 \pm 25.46(b)$ & $8.2-157.2$ \\
\hline GGT (IU/L) & $1.05 \pm 0.30(\mathrm{a})$ & $0.6-1.2$ & $2.38 \pm 1.29$ (b) & $0.6-5.7$ \\
\hline Total Protein (serum) (g/dL) & $6.73 \pm 1.01$ & $5.9-8.2$ & $6.56 \pm 0.66$ & $4.6-9.4$ \\
\hline $\operatorname{Albumin}(\mathrm{g} / \mathrm{dL})$ & $2.63 \pm 0.45$ & $2-2.9$ & $3.05 \pm 0.66$ & $2-6.2$ \\
\hline Globulin (g/dL) & $4.1 \pm 1.45$ & $3.1-6.3$ & $3.51 \pm 1.03$ & $1.9-7.5$ \\
\hline Fibrinogen (mg/dL) & $100 \pm 0(a)$ & 100 & $186.05 \pm 108.19(\mathrm{~b})$ & $100-600$ \\
\hline
\end{tabular}

$\overline{{ }^{a}}$ Means in the same column (line) with different superscripts are significantly different $(\mathrm{P}<0.05)$.

animals) showed one cross of bilirubin. All urinary parameters cited above were in accordance with the reference values for domestic dogs (Lees et al. 1994).

All kinds of lining cells were observed in the sediment analysis, mainly vesicle cells, according to reference values proposed for domestic dogs (Lees et al. 1994). WBC, bacteria and casts (hyaline and granular) were found in several samples, but not over the reference values for domestic dogs (Lees et al. 1994).
Table 5. Urinary values (mean $\pm \mathrm{SD}$, range and coefficient of variation) for $\mathbf{2 4}$ males captive Crab-eating fox (Cerdocyon thous) in São Paulo state, Brazil

\begin{tabular}{lccc}
\hline Parameters & Mean \pm SD & Range & CV \\
\hline $\mathrm{SG}^{\mathrm{a}}$ & $1.027 \pm 0.01$ & $1.008-1.040$ & 1.11 \\
Proteins $(\mathrm{mg} / \mathrm{dL})$ & $107.71 \pm 155.96$ & $0-500$ & 144.80 \\
Glucose $(\mathrm{mg} / \mathrm{dL})$ & $13.75 \pm 61.28$ & $0-300$ & 445.65 \\
$\mathrm{pH}$ & $6.60 \pm 0.82$ & $5-8$ & 12.43 \\
\hline
\end{tabular}

${ }^{\text {a }}$ Specific gravity. 
As for occult blood, there were variations from 1 to 3 crosses (75\% of the animals - 18 in 24 animals), with the presence of RBC ( $25 \%$ of the animals - 6 in 24 animals) in several analyzed sediments. They varied from rare to $35-40$ RBC by microscopic visual field.

Bacteria found in urine varied from rare to three crosses. And the amorphous urate crystal was the most found in urine samples (54.2\% of the animals, 13 in 24 animals) followed by amorphous phosphate $(8.3 \%, 2$ in 24 animals) and triple phosphate $(4.2 \%, 1$ in 24 animals).

\section{DISCUSSION}

\section{Hematology}

In this study, the hematological values for captive Crab-eating foxes were not affected by gender; however, some sexual differences for hematological parameters were described for other species of wild canids, as Swift Fox (Mainka 1988), The Island Fox on Santa Cruz Island (Urocyon littoralis) (Crooks 2000) and Wild Coyote (Canis latrans) (Smith \& Rongstad 1980).

Most mean hematological values found in this research were in accordance to the reference interval for domestic dogs (Jain 1993), exception made for RBC, which was under those values, and Mean Corpuscular Volume (MCV) and $\mathrm{MCH}$, which were higher than those values. Those data confirm the need for obtaining specific reference values for Cerdocyon thous.

RBC, hemoglobin and PCV values have showed variation when compared to other authors that work with $C$. thous, being lower, upper or even similar. An example was the RBC value, which was lower than those for Crab-eating fox obtained by other authors (Hoehne \& Rosenfeld 1953, Santos 1999, Novais et al. 2005, Santos-Júnior et al. 2006).

It is important to note that MCV and $\mathrm{MCH}$ of Crab-eating fox were higher than those for domestic dogs, and that this difference is remarkable. So, it is possible to affirm that RBC of the Crab-eating fox is bigger (high MCV) and it has more hemoglobin (high MCH), however, with a mean hemoglobin concentration per normal volume (normal MCHC), always compared to the RBC of domestic dog. MCV values for Crab-eating fox obtained in this research and in the other study (Novais et al. 2005) showed to be superior to the values for Maned wolves found by Novais et al. (2005). However, MCV and MCH for Swift fox showed lower values compared to the domestic dog (Mainka 1988), and this can explain that there is a variability of these parameters among wildlife canids.

RBC indices (MCV, MCH and MCHC) found in this study were similar to those observed in other study using captive crab-eating fox (Novais et al. 2005). On the other hand, lower values were observed by other authors in free-living crab-eating fox (Santos-júnior et al. 2006). The difference in RBC indices in wildlife canids could have occurred due to the difference between free-living (Santos-Júnior et al. 2006) and captive (Novais et al. 2005) crab-eating foxes. This was demonstrated in C. thous by other author (Santos 1999).

Only $16.7 \%$ (9 in 52 animals) showed the presence of one metarrubrycite in 100 WBC counted during the differential examination. As for domestic dogs, just one nucleate
RBC can be found in healthy animals (Jain 1993) and, this way, it was considered normal the amount of metarrubrycites showed in this research.

The values obtained for total WBC were inferior to all values found in the literature with crab-eating fox (Hoehne \& Rosenfeld 1953, Santos 1999, Novais et al. 2005, Santos-Júnior et al. 2006). However they were in agreement with the reference values proposed for domestic dogs (Jain 1993).

Absolute values found during the differential WBC count were very similar to those for domestic dogs (Jain 1993), with a predominance of segmented neutrophils followed by lymphocytes. Values obtained for band and segmented neutrophils and lymphocytes were lower than most values found in the literature for Crab-eating fox (Santos 1999, Novais et al. 2005, Santos-Júnior et al. 2006). It shows that even with the utilization of physical and chemical methods of animal restraint there was no increase of WBC, segmented neutrophils and lymphocytes values. This fact might have occurred due to physiologic leukocytosis related to acute stress or fight-or-flight reaction with splenic contraction and displacement from the marginal to the circulating pool. In sub-adult animals, lymphocytosis may have occurred, also, by an increase in the numbers of lymphocytes which is based on an increase in antibody production and immune system regulation (Jain 1986).

Values found for eosinophils and basophils were higher than those in literature (Santos 1999, Novais et al. 2005, Santos-Júnior et al. 2006), which could have occurred due to the presence of endoparasites and ectoparasites (Jain 1986). Eosinophils for Crab-eating fox showed to be morphologically different from those of domestic dogs, with bigger eosinophilic granules, having a cell morphologically similar to the equine's eosinophils. Those ones showed vacuoles, which can be cytoplasmic granules that suffered degranulation. Values for monocytes showed to be higher than those found by some researchers (Santos 1999, Novais et al. 2005), but being similar to others (Santos-Júnior et al. 2006).

Platelet count was in normal range proposed for domestic dogs (Jain 1993), in accordance with the values found for Bush Dog (Speothos venaticus) (Gomes 2007), showing that even with a period of 24 hours between collection and processing of biological samples, there was no platelet aggregation. This fact could be due to a calm collection, the use of plastic bottles and the material maintenance under refrigeration from the collection from the beginning of the processing.

In this research, some hematological parameters were affected by aging despite the data by other authors (May-Junior et al. 2009) which has shown that aging did not affect those parameters in Maned Wolves. Erythrocyte parameters (RBC, Hemoglobin and PCV) found in sub-adult animals were lower than those found in adult animals; however only Hemoglobin showed significant differences. In dogs, RBC, PCV and hemoglobin values are higher at birth but they fall rapidly when animals start to grow. That reduction is related to the increase of fetal RBCs destruction as well as to a rapid growth of the animal, not to mention 
that this decrease in red blood cells occurs up to the first month of life. After that period, there is an increase in hemoglobin and PCV until 18 months of age (reaching its peak between 13 months and 2 years old) (Jain 1986). This same difference between erythrocyte parameters in sub adult and adult was found for Wild Coyotes (Smith \& Rongstad 1980), The Island Fox on Santa Cruz Island (Crooks 2000) and for Maned Wolves (May-Junior et al. 2009), all of them without statistical differences.

Red blood cell indices (MCH and MCHC) showed significant statistical differences between sub-adult and adult animals, with higher results for older animals, as also observed in The Island Fox on Santa Cruz Island (Crooks 2000). This fact should have occurred due to a bigger reduction of hemoglobin which, consequently, could take it to reductions in MCH and MCHC in sub-adult animals, besides that, in domestic dogs, MCHC decreases after birth and up to 2 months of life, gradually increasing after that up to adult age (Jain 1986).

Values found for WBC, segmented neutrophils and lymphocytes were statistically higher in sub-adult animals when comparing to those found in adult animals, as also observed in domestic dogs (Jain 1986), and The Island Fox on Santa Cruz Island (Crooks 2000) (for this one just relative values of lymphocytes were higher in sub-adult animals). Young animals seemed to be more stressed out with physical and chemical restraint, and this way it could have occurred a physiologic increase in WBC, with an increase of the number of WBC, segmented neutrophils and lymphocytes when comparing with adult animals.

The values for band neutrophils in sub-adult animals were statistically higher than those found in adult animals; however they are still in the normal range proposed for domestic dogs (Jain 1993). Even being short values, they can be considered normal, either for adult, or for sub-adult animals. Other authors did not observe statistical differences for leukocyte parameters between young and adult wild coyotes (Smith \& Rongstad 1980) and Maned wolves (May-Junior et al. 2009).

\section{Serum biochemistry}

Serum biochemistry values were not affected by gender. According to another research (Crooks 2000), male and female Island Fox on Santa Cruz Island did not show differences on serum biochemical values. On the other hand, some researches with wildlife canids showed some differences in biochemical parameters among male and female animals from the same species (Zhan et al. 1991, Aroch et al. 2005, May-Junior et al. 2009).

All serum biochemical values for Crab-eating fox are in the reference range for domestic dogs (Kaneko et al. 1997), agreeing with another study of Crab-eating fox (Neves-Júnior et al. 2006). This agreement with serum biochemical values for domestic dogs has also occurred in Silver Fox (Zhan et al. 1991) and Golden Jackals (Aroch et al. 2005), showing that other wildlife canids can have some similarity to domestic dogs.

Urea values, in this research, were similar to all studies in literature with Crab-eating fox (Santos 1999, Novais et al. 2005, Neves-Júnior et al. 2006); creatinine values were similar to those found by other authors (Novais et al. 2005), and superior to other (Santos 1999, Neves-Júnior et al. 2006), showing higher values, but still in the reference range for domestic dogs (Kaneko et al. 1997). Data from another study showed urea values higher than the reference values for domestic dogs in captive Crab-eating fox (Iba et al. 1996).

Liver enzymes (ALT, ALP and GGT) showed a small variation when compared to values found in the literature for Crab-eating fox (Santos 1999, Novais et al. 2005, Neves-Júnior et al. 2006). However, they were always in the reference range for domestic dogs, agreeing with the findings in the Maned Wolves (Dittrich et al. 2003), and in Bush Dog and Maned Wolf (Gomes 2007).

Total Protein (serum) and Albumin values were lower than those reported for Crab-eating Fox (Novais et al. 2005, Neves-Júnior et al. 2006). For Maned Wolves, Total Protein (serum) and Albumin were similar to those data for domestic dogs (Dittrich et al. 2003), showing that other wildlife canids can have similar values to the ones of domestic dogs.

Fibrinogen value was higher than the one described by some authors (Santos 1999) and lower than the one described by others (Neves-Júnior et al. 2006). Mean values of fibrinogen for Vulpes fulva and Canis lupus were $200 \mathrm{mg} / \mathrm{dL}$ and $100 \mathrm{mg} / \mathrm{dL}$, respectively (Jain 1993).

Urea values were significantly bigger in adults when compared to sub-adults, contradicting the findings in wild coyotes (Smith \& Rongstad 1980), which did not show significant differences in urea related to aging. Probably, adult animals had a higher-protein diet, explaining the higher levels of urea in older animals. Blood urea concentration is used to evaluate the renal function, and it is a sensible and fast indicator of protein ingestion, and blood urea elevation can be caused by protein consumed in excess or reduction of glomerular filtration (Finco 1997). ALP values were expressively higher in sub-adult animals, and this increase was expected due to the increase of osseous formation and osteoclasts differentiation in young animals (Seal et al. 1975, Kirk et al. 1990, Tennant 1997). GGT and fibrinogen values were higher in adults when compared to sub-adult animals, being considered as normal for both (adult and sub-adult) because they were in the reference range proposed for domestic dogs (Kaneko et al. 1997).

\section{Urinalysis}

The slight increase of proteinuria probably was due to the presence of spermatozoons in urine $37.5 \%$ of the animals, 9 in 24 animals) and occult blood (RBC and/or hemoglobin). Two animals that had 1 cross of billirrubin did not show decrease in urine specific gravity, not even the presence of crystals or bilirubin impregnation, since this alteration can be considered normal in the same way as it does for domestic dogs (in urine samples with elevated specific gravity) (Jain 1986).

Presence of occult blood in urine and /or RBC in the analyzed sediments can have occurred by penis or urethra lesions due to introduction of the urethral tube for urine collection. The presence of bacteria in urine has probably 
occurred due to contaminations in the introduction of the urethral tube and to the time between collection and processing of samples, since other alterations compatible to cystitis, as the presence of WBC in the urinary sediment, was not observed.

The quantity of crystals has probably increased in the urine samples due to the time spent from collection to the processing of the samples, and by the fact that samples were kept under refrigeration. Captive nutrition made with high-protein diet (animal origin) can induce to a higher incidence of urine crystals, according to the observation of Maned wolves (Bush \& Bovée 1978, Barbiers \& Bush 1995, Santiago \& Oliveira 2001).

\section{CONCLUSIONS}

Hematological, serum biochemistry and urinary values obtained in this study can be used as physiological values of Crab-eating fox, helping and supporting clinical evaluations for this species.

Differences between adult and sub-adult animals should be always observed, showing the necessity of reference values utilization for the species, considering that the differences were observed in relation to domestic dog.

Acknowledgments.- This study was supported by Training Special Program (PET-SESu/MEC) and Veterinary Clinical Laboratory of the School of Veterinary Medicine and Animal Science, São Paulo State University. The authors wish to thank Mariângela L. Cruz and Rodrigo L. Maruccio for helping with field procedures, and Mariane Helena V. B. T. Augusto for helping in the laboratory analysis.

\section{REFERENCES}

Almosny N.R.P. \& Monteiro A.O. 2007. Patologia clínica, p.939-966. In: Cubas Z.S., Silva J.C.R. \& Catão Dias J.L. (Eds), Tratado de Animais Selvagens: medicina veterinária. Roca, São Paulo.

Aroch I., Shpigel N.Y., Avidar Y., Yakobson B., King R. \& Shamir M. 2005. Haematological and biochemical measurements in healthy, adult, freeranging Golden jackals (Canis aureus syriacus) held in captivity. Vet. Rec. 157(11):317-21.

Barbiers R. \& Bush M. 1995. Medical management of Maned Wolves. In: Fletchal N.B., Rodden M. \& Taylor S. (Eds), Husbandry Manual for the Maned Wolf (Chrysocyon brachyurus). Smithsonian Institution Press, Washington. 75p.

Berta A. 1982. Cerdocyon thous. Mammalian Species 186:1-4.

Busch H. 1980. Medical management of Maned wolves (Chrysocyon brachyurus). In: Proceedings of American Association of Zoo Veterinarians, Washington, p.131-132.

Bush M. \& Bovée K.C. 1978. Cystinuria in a Maned wolf. J. Am. Vet. Med. Assoc. 73(9):1159-1162.

Cavaliero I.C. 1989. Valores hematológicos, bioquímicos do soro e temperatura interna de Lobos Guará (Chrysocyon brachyurus). Ars Vet. 5(1):25-32.

Constable P., Hinchcliff K., Demma N., Callahan M., Dale B., Fox K., Adams L., Wack R. \& Kramer L. 1998. Serum biochemistry of captive and free-ranging Gray wolves (Canis lupus). J. Zoo Wildl. Med. 29(4):435-440.

Courtenay O., Quinnell R.J. \& Chalmers W.S.K. 2001. Contact rates between wild and domestic canids: No evidence of parvovirus or canine distemper virus in Crab-eating foxes. Vet. Microbiol. 81(1):9-19.

Crooks K.R., Scott C.A., Bowen L. \& Van Vuren D. 2000. Hematology and serum chemistry of the Island Fox on Santa Cruz island. J. Wildl. Dis. 36(2):397-404.

Dittrich R.L., Schmidt-Popazoglo E.M.S., Mangrich-Rocha R.M.V., Penso
G.C., Saito M.E., Silva S.F.C., Passerino A.S., Lacerda O.P., Javorouski M.L., Pachaly J.R. \& Lange R.R. 2003. Valores hematológicos e bioquímicos de Lobos Guará (Chrysocyon brachyurus), em cativeiro no estado do Paraná, Brasil. Arq. Ciênc. Vet. Zool. 6(1):71-76.

Facure K.G. \& Monteiro-Filho E.L.A. 1996. Feeding habits of the Crabeating fox, Cerdocyon thous (Carnivora, Canidae), in a suburban area of southeastern Brazil. Mammalia 60(1):147-149.

Finco D.R. 1997. Kidney function, p.441-484. In: Kaneko J.J., Harvey J.W. \& Bruss M.L. (Eds), Clinical Biochesmistry of Domestic Animals. $5^{\text {th }}$ ed. Academic Press, San Diego, California.

Ginsberg J.R. \& Mcdonald D.W. 1990. IUCN/SSC Canid Specialist Group. IUCN Publications, Gland, Switzerland, p.116.

Gomes M.S. 2007. Carnívora - Canidae (lobo guará, cachorro do mato, raposa do campo), p.492-504. In: Cubas Z.S., Silva J.C.R. \& Catão Dias J.L. (Eds), Tratado de Animais Selvagens: medicina veterinária. Roca, São Paulo.

Hoehne L. \& Rosenfeld G. 1953. Dados hematológicos do Cachorro do mato (Cerdocyon thous azarae). Estudos de hematologia comparada II. Mem. Inst. Butantan 25(2):55-57.

Iba A.M., Santana A.E., Camacho A.A., Puglia L.R. \& Nunes A.L.V. 1996. Determinação de parâmetros clínico-laboratoriais em cachorros-do-mato (Cerdocyon thous). Hora Vet. 16(92):43-46.

Jain N.C. 1986. The dog: normal hematology with comments on response to disease, p.103-125. In: Jain N.C. (Ed.), Schalm's Veterinary Hematology. $4^{\text {th }}$ ed. Lea and Febiger, Philadelphia.

Jain N.C. 1993. Comparative hematology of common domestic animals, p.19-54. In: Jain N.C. (Ed.), Essentials of Veterinary Hematology. Lea and Febiger, Philadelphia.

Kaneko J.J. 1997. Serum proteins and dysproteinemias, p.121-121. In: Kaneko J.J., HarveyJ.W. \& Bruss M.L. (Eds), Clinical Biochesmistry of Domestic Animals. $5^{\text {th }}$ ed. Academic Press, San Diego, California.

Kaneko J.J., HarveyJ.W. \& Bruss M.L. 1997. Appendixes, p.895-899. In: Kaneko J.J., HarveyJ.W. \& Bruss M.L. (Eds), Clinical Biochesmistry of Domestic Animals. $5^{\text {th }}$ ed. Academic Press, San Diego, California.

Karesh W.B., Hart J.A., Hart T.B., House C., Torres A., Dierenfeld E.S., Braselton W.E., Puche H. \& Cook R.A. 1995. Health evaluation of five sympatric duiker species (Cephalophus spp.). J. Zoo Wildl. Med. 26(4):485-502.

Kirk R.W., Bistner S.I. \& Ford R.B. 1990. Handbook of Veterinary Procedures and Emergency Treatment. $5^{\text {th }}$ ed. W.B. Saunders Co., Philadelphia, Pennsylvania. 1016p.

Lees G.E., Willard M.D. \& Green R.A. 1994. Urinary disorders, p.120-136. In: Willard M.D., Tvedten H. \& Turnwald G.H. (Eds), Small Animal Clinical Diagnosis by Laboratory Methods. $2^{\text {nd }}$ ed. W.B. Saunders Co., Philadelphia.

Mainka S.A. 1988. Hematology and serum biochemistry of captive Swift foxes (Vulpes velox)..J. Wildl. Dis. 24(1):71-74.

May-Junior J.A., Songsasen N., Azevedo F.C., Santos J.P., Paula R.C., Rodrigues F.H.G., Rodden M.D., Wildt D.E. \& Morato R.G. 2009. Hematology and blood chemistry parameters differ in free-ranging Maned wolves (Chrysocyon brachyurus) living in the Serra da Canastra National Park versus adjacent farmlands, Brazil. J. Wildl. Dis. 45(1):81-90.

McDonald D.W. \& Courtenay O. 1996. Enduring social relationships in a population of Crab-eating zorros, Cerdocyon thous, in Amazonian Brazil (Carnivora, Canidae). J. Zool. 239:329-355.

Motta-Júnior J.C., Lombardi J.A. \& Talamoni S.A. 1994. Notes on Crab-eating fox Dusicyon thous seed dispersal and food habits in southeastern Brazil. Mammalia 58(1):156-159.

Neves-Júnior J.M., Santos-Júnior T.S., Marques S.R., Meyer-Júnior J.C. \& Vilar T.D. 2006. Avaliação bioquímica sérica em Cachorros do mato (Cerdocyon thous) de vida livre na Fazenda Panflora, Jangada, MT. Revta Univ. Rural, Sér. Ciênc. Vida 26(Supl.):27-28.

Novais A.A., Fagliari J.J. \& Santana A.E. 2005. Valores sangüíneos de referência e investigação sobre a presença de antígenos eritrocitários caninos (DEA - dog erythrocyte antigen) em Lobos-guarás (Chrysocyon brachyurus) e Cachorros-do-mato (Cerdocyon thous). Vet. Notícias 11(1): 59-67. 
Nowak R. M. 1999. Walker's Mammals of the World. $6^{\text {th }}$ ed. Johns Hopkins University Press, Baltimore, p.634-678.

Rodrigues A.S.M. \& Auricchio P. 1994. Canídeos do Brasil, Coleção Terra Brasilis. Série Zoologia - Zoo IV. Mamíferos do Brasil. Terra Brasilis, Arujá. 13p.

Santiago M.E.B. \& Oliveira L.T.F. 2001. Order Carnívora, family Canidae (dogs, foxes, Maned Wolves): Medicine, p.285-290. In: Fowler M.E. \& Cubas Z.S. (Eds), Biology, Medicine and Surgery of South American Wild Animals. Iowa State University Press, Ames.

Santos L.C. 1999. Laboratório Ambiental. Editora Universitária - Edunioeste, Cascavel, p.260-263.

Santos-Júnior T.S., Neves-Júnior J.M., Marques S.R., Meyer-Júnior J.C. \& Vilar T.D. 2006. Avaliação hematológica em Cachorros do mato (Cerdocyon thous) de vida livre, residentes na Fazenda Panflora, Jangada, MT. Revta Univ. Rural, Sér. Ciênc. Vida. 26(Supl.):25-26.

Seal U.S., Mech L.D. \& Van Ballenbergue V. 1975. Blood analyses of wolf pups and their ecological and metabolic interpretation. J. Mammal. 56(1):64-75.
Searcy R.L. 1969. Diagnostic Biochemistry. McGraw-Hill Co., New York, NY. $660 \mathrm{p}$.

Smith G.J. \& Rongstad O.J. 1980. Serologic and hematologic values of wild coyotes in Wisconsin. J. Wildl. Dis. 16(4):491-497.

Tennant B.C. 1997. Hepatic function, p.327-352. In: Kaneko J.J., Harvey J.W. \& Bruss M.L. (Eds), Clinical Biochesmistry of Domestic Animals. $5^{\text {th }}$ ed. Academic Press, San Diego, California.

Van Heerden J., Burroughs R.E.J., Dauth J. \& Dreyer M.J. 1991. Immobilization of Wild dogs (Lycaon pictus) with a tiletamine hydrochloride/ zolazepam hydrochloride combination and subsequent evaluation of selected blood chemistry parameters. J. Wildl. Dis. 27(2):225-229.

Wallach J.D. \& Boever W.J. 1983. Canidae, p.404-463. In: Wallach J.D. \& Boever W.J. (Eds), Diseases of Exotic Animals: Medical and surgical management. W.B. Saunders, Philadelphia.

Zhan Y.M., Yasuda J. \& Too K. 1991. Reference data on the anatomy and serum biochemistry of the Silver fox. Jpn. J. Vet. Res. 39(1):39-50. (Abstract) 